\title{
Factors Determining Rural Youth Participation in Agriculture-Based Livelihood Activities: A Case Study of Karsog in Himachal Pradesh
}

\author{
Rashmi Chaudhary*, Yasmin Janjhua, Nikhil Sharma, Deepika Sharma, Ankit Pathania and Krishan Kumar
}

Dept. of Business Management. College of Horticulture, Dr Y. S. Parmar University of Horticulture and Forestry, Nauni, Solan, Himachal Pradesh (173 230), India

\section{Corresponding Author}

Rashmi Chaudhary

e-mail: rashmihpu@gmail.com

\author{
Article History \\ Article ID: IJEP0302 \\ Received in $11^{\text {th }}$ April, 2019 \\ Received in revised form 06 ${ }^{\text {th }}$ May, 2019 \\ Accepted in final form $17^{\text {th }}$ May, 2019
}

\begin{abstract}
Engagement of rural youth in agriculture based livelihood activities is gaining attention as a strategy to mitigate current problem of unemployment due to employment potential of these activities. Nonetheless, there have been evidences about declining youth participation in agriculture based livelihood activities. The present study investigated the factors determining rural youth participation in agriculture based livelihood activities. Examination of a sample of 250 youth respondents identified; agricultural knowledge, availability of land, interest in agriculture, fertile soil, favourable environment \& temperature, availability of different types of soil, good transportation facilities and well connectivity as some of the factors determining rural youth participation in agriculture-based livelihood activities in the study area. The overall results for predominant agricultural based activities in which youth participate indicates that youths in the study area are not significantly engaged in agriculture based livelihood activities. However crop farming and livestock rearing are the two major activities in which they are involved. The results of the study will have some useful implication for the policy makers and it is recommended that all stakeholders must make efforts to create favourable environment for increasing youth participation in agriculture based livelihood activities.
\end{abstract}

Keywords: Agriculture, rural youth, livelihood, determinants, factors

\section{Introduction}

Despite impressive economic growth, Himachal Pradesh is confronted with the current problem of unemployment among rural youth. Engagement of rural youth in agriculture based livelihood activities is gaining attention realising its employment potential. The Role of agriculture in the rural economy is of importance that agriculture development and rural development can be used interchangeably. However, agriculture remains unattractive to the youth leading to their movement from rural to urban in search of opportunities and better life (Gangwar and Kameswari, 2016). A number of recent occurrences suggest that India might very well be at the "tipping point" of the (de)growth in its agricultural population. Further, the agricultural future of the country may be bleak if left in the hands of aged subsistent farmers who presently constitute the major farming population. Moreover, given the growing urbanization, better literacy standards, and greater skill attainment by the rural youth, the proportion of the latter in the agricultural labor force could drop substantially, thus, changing drastically the nature of farming in the country (Bhaduri and Sharma, 2009).
Despite of the fast growing opportunities in agriculture based livelihood activities, it is alarming and quite incredible to see many rural youths opting out of farming in search of non-existed white-collar jobs in the cities, leading to unprecedented level of rural-urban migration (Adekunle et. al., 2009). Youth are an important and vital segment of human resources that can shoulder the responsibility of development including agriculture (Skuza, 2005). Youth are the carriers of new ideas and are more receptive to innovation, ready to bear risk and willing to participate in community action (Damar, 2008).

Noticeably, about $70 \%$ India's population is below the age of 35 years, making it the youngest nation in the World and this predominance is expected to last until 2050 which can be utilized for taking Indian agriculture to new heights by channelizing their creative energies through development of appropriate skills, knowledge and attitude (Gangwar and Kameswari, 2016). Youth involvement in agriculture is significant as they are excellent source of ideas and innovations, they have the required energy and ability and tendency to learn and grasp new ideas or technologies faster. Although agriculture is perceived as the significant alternative 
solution to youth's unemployment and ability to overcome economic issues, it seems that youth have negative attitudes toward agriculture. They are not interested to join agriculture because they do not view the agriculture field as an attractive area to work (Abdullah, 2012). It is disturbing to note that our youth are losing interest and confidence in agriculture and allied activities; hence they are not willingly involved in agricultural operations (Rani and Rampal, 2016). In the coming years, one of the biggest challenges for Indian agriculture would be retaining its youth in agriculture. It has become imminent to reorient agricultural practices to make them intellectually satisfying and economically rewarding for the youth (Jayapuria, 2015). Unless farming becomes both intellectually stimulating and economically rewarding, it will be difficult to attract or retain rural youth in farming (Swaminathan, 2001).

Himachal Pradesh is predominantly an agricultural State where Agriculture, Horticulture, Fisheries and Animal Husbandry provide direct employment to about 71 percent of the total population. Youth involvement in agriculture remains critical given the direct and indirect benefits of agriculture (Kwenye and Sichome, 2016). Poor participation of youth in agriculture and allied activities in the state of Himachal Pradesh has been a problem to agriculturists as well and administration (Chaudhary et al., 2017). Integration of youth in agricultural activities is an important factor for overall agricultural and economic development because of their innovative attitude, physical strength and adapting to latest technologies. Though research has been conducted on youth involvement in agriculture but there are still knowledge gaps on factors determining rural youth participation in agriculture-based livelihood activities. Present study is an attempt in this direction.

Present study is an attempt to investigate rural youth participation in agriculture-based livelihood activities and to analyse the factors determining rural youth participation in agriculture-based livelihood activities in the study area.

\section{Materials and Methods}

It is fairly well-known from the available facets of the residents of Karsog that only certain segments of the population are of direct interest for the present study. As such the focus for collection of data has been on the subjectively but relevant segments of the population. Sample for the present study constituted 250 youths selected using purposive sampling technique in the age group of 18-40 years living in Tehsil Karsog of Himachal Pradesh. In terms of geographical location, scope of the study has been restricted to Karsog in Himachal Pradesh. Pre-structured questionnaire developed by the researchers after reviewing previous works was used to determine the perceptions of youth respondents regarding factors determining their participation in agriculture based livelihood activities. For collecting data on perceived factors determining youth participation in agriculture based livelihood activities, five-point likert scale was used. Each respondent was asked to indicate his/her extent of agreement or disagreement against each statement along a 5-point likert scale: Strongly Agree (SA), Agree (A), Undecided (U), Disagree (D) and Strongly Disagree (SD). Weights assigned to these responses were 5,4,3,2, and 1 respectively.

\section{Results and Discussion}

Table 1 reveals that sample respondents of every age group were involved in the agricultural activities but a large majority of the respondents $(74.8 \%)$ belonged to the age group (1925). Tabulated representation put forth that most of the respondents engaged in agricultural and allied activities were educated and unmarried. It is heartening to know that even post graduate people were engaged in such activities in the study area. Findings of the study show that males were more involved in agricultural and allied activities as compared to females. It is evident from the findings that even though $37.2 \%$ of the respondent families are engaged in farming activities, nearly half of the respondents were unemployed. Majority of the respondents were having agricultural sector as their primary occupation followed by business. It is quite evident from the tabulated representation that marginal farmers have the highest number of percentage as about $92 \%$ of the sampled respondents were marginal farmers and only $8 \%$ were small farmers who have $1-2$ hectare of land. It is apparent from the table that $36.4 \%$ of the respondents fall in the category of annual income of 50 thousand to 1 lakh and $24 \%$ of the respondents had annual income above 2 lakh.

Brooks et al. (2012) and Kararach et al. (2011) reveal that creation of non-agricultural jobs may not happen in the short run; as such agriculture is likely to continue being a source of employment and livelihood in the medium to long term especially for countries that heavily depend on agriculture. It is evident from Table 2 that majority of sampled youth were involved in crop farming followed by livestock rearing. Similar findings were reported by Oladeji (2007); Nandini and Kiresur (2013) that crop production is the most participated agricultural income generating activities among rural dwellers. Further, it was revealed that about $29.6 \%$ youth were involved in bee keeping, $26.8 \%$ in farm labour services, $26 \%$ in trading agricultural inputs and $21.2 \%$ in transportation of agricultural products. Other activities in which youth participation was seen were farm implements hiring services (19.6\%) and processing agricultural products (14.8\%). A small number of youth i.e. only $10 \%$ were involved in fishing. The overall results indicate that youths in the study area are not significantly engaged in agriculture based livelihood activities. There is insufficient youth participation in the agricultural sector (Mangal, 2009) even though this class of people is the most productive of any society as it contains people in the prime of their lives physically and mentally. Okoye (1995); CPD (2004); Oladeji (2007); Ovwigho (2014) reported that even 


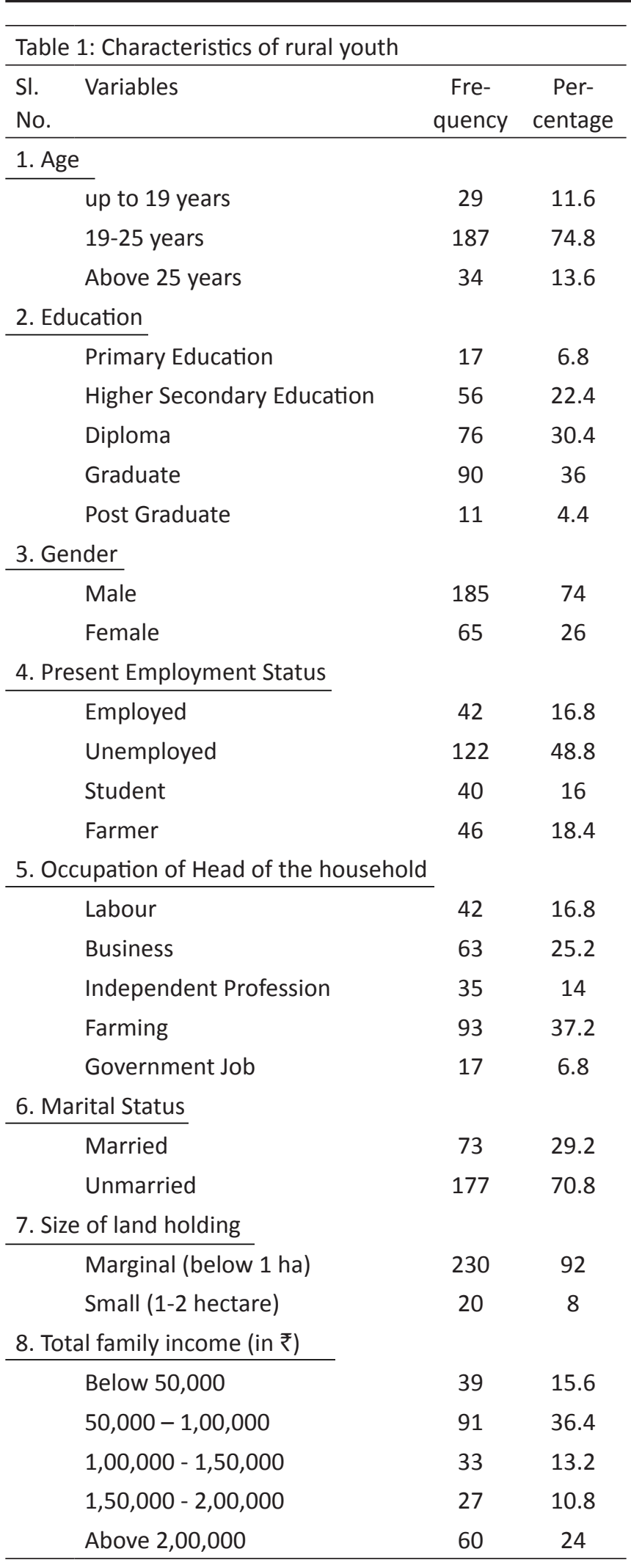

though farming is the predominant activity in most rural areas, rural dwellers usually engage in non-farm income generating activities. The findings support the view of Bennell (2010) who was of the view that rural youth are engaged in a diverse range
Table 2: Predominant agricultural based livelihood activities youth participate in the study area

\begin{tabular}{lcc}
\hline Agricultural activities & Involved & Not involved \\
\hline Bee keeping & $74(29.6)$ & $176(70.4)$ \\
Fishing & $25(10)$ & $225(90)$ \\
Crop farming & $109(43.6)$ & $141(56.4)$ \\
Trading agricultural inputs & $65(26)$ & $185(74)$ \\
Farm labour services & $67(26.8)$ & $183(73.2)$ \\
Livestock Rearing & $86(34.4)$ & $164(65.6)$ \\
Transportation of & $53(21.2)$ & $197(78.8)$ \\
agricultural products & & \\
Processing of agricultural & $37(14.8)$ & $213(85.2)$ \\
products & & \\
Farm implements hiring & $49(19.6)$ & $201(80.4)$ \\
services & & \\
\hline Note: Figures in parenthesis are in percentages
\end{tabular}

of productive activities both agricultural and non-agricultural which make up their livelihood strategies.

Table 3 reveals the factors determining the youth participation in agricultural activities. The result reveals that fertile soil of the region has scored the highest mean value $(M=4.32)$ and thus is the biggest motivator for youth's involvement in agriculture-based livelihood activities in the study area. Analysis of the mean score reveals that absence of other job alternatives ( $M=4.08)$ and agricultural knowledge $(M=3.74)$ are other important factors determining youth participation. The study by Rutta (2012) showed that young people both in urban and rural areas revealed that agriculture is the last career or job choice. For many people agriculture remains an old fashioned sector, a sector that cannot generate income for their living. Barau and Afrad (2017) supported the finding that inclusion of agriculture in all levels of education $(M=3.70)$ is an important factor determ ining youth participation in agriculture based livelihood activities. They further opined that promotion of high value agriculture, precision farming, organic cultivation, Hi-Tech horticulture, micro-propagation, Integrated Pest Disease and Nutrients Management, Post Harvest Management, development of backward and forward linkages etc., require well trained young farmers with enthusiasm and passion for farming and ability to take risks. The results further revealed that other important factors determining rural youth participation in agriculture based livelihood activities are; fulfill socio-economic needs $(M=3.68)$, availability of land $((M=3.64)$ and favourable environment and temperature $(M=3.52)$. Youth from all around the world see secure access to land as fundamental for entering farming (FAO, 2014). Youth's Interest in agriculture $(\mathrm{M}=3.30)$, good transportation facility and well connectivity $(M=3.20)$, availability of forest around the region $(M=3.16)$ and sufficient rainfall $(M=3.08)$ are other factors. Further mean 
Table 3: Factors determining rural youth participation in agriculture and allied activities

\begin{tabular}{lcc}
\hline Statement & Mean & $\begin{array}{c}\text { Std. } \\
\text { deviation }\end{array}$ \\
\hline Lack of job alternative & 4.08 & 0.90 \\
Agricultural knowledge & 3.74 & 0.82 \\
Interest in agriculture & 3.30 & 0.78 \\
Availability of rural credit facilities & 2.76 & 1.00 \\
Availability of land & 3.64 & 0.82 \\
Various government schemes and & 2.76 & 1.06 \\
incentives & & \\
Technological advancements & 2.60 & 1.10 \\
Fertile soil of the region & 4.32 & 0.79 \\
Environment and temperature is fa- & 3.52 & 0.93 \\
vourable & & \\
Availability of forest around the region & 3.16 & 0.95 \\
$\begin{array}{l}\text { Sufficient rainfall } \\
\text { Transportation facility and well con- }\end{array}$ & 3.20 & 0.72 \\
$\begin{array}{l}\text { nectivity } \\
\text { Inclusion of Agriculture in all levels of }\end{array}$ & 3.70 & 0.76 \\
education & & \\
Agriculture and allied activities can ful- & 3.68 & 0.74 \\
fil rural youth's socio-economic needs & & \\
\hline
\end{tabular}

analysis reveals that factors which do not contribute much in participation of rural youth in agriculture based livelihood activities are availability of rural credit facilities (( $M=2.76)$, various government schemes and incentives $(M=2.76)$ and technological advancements $(M=2.60)$. Based on the descriptive results from the study, it can be concluded that availability of congenial inputs like fertile soil, environment, temperature, rain etc are the major factors which determine youth participation in agriculture. The future of any country is intimately connected with that of its young people. The importance of youth as key agents for development of a nation has been amply recorded in many national and international development policies. Rural youth constitute a significant proportion of India's population. For the development of the nation as well as youth it is necessary to involve rural youth in agriculture. Their active participation is possible only if they are imparted relevant concepts and issues related to agriculture.

\section{Conclusion}

Based on the descriptive results from the study, it can be concluded that youth of the study area are not significantly engaged in agriculture based livelihood activities. It is suggested that a number of incentives are needed to convince youths that agriculture can provide a good career. Moreso, rural youth should organize themselves in groups/cooperatives in order to share knowledge and experience for the improvement of their productive abilities. Government should design adequate policies and legislation for encouraging rural youth's interest and participation.

\section{Further Research}

The study was conducted in Karsog Tehsil of Himachal Pradesh. It can be replicated by similar research design in other places of the country where comparable socio-economic and physical condition exist in order to confirm present research findings. Only fifteen factors determining rural youth participation in agriculture and allied activities were included in present study. Thus, there are obviously other important factors which can be explored, hence further study is needed by the concerned agencies in this area.

\section{References}

Abdullah, F.A., 2012. Inclination toward agriculture among rural youth in Malaysia. Journal of Basic and Applied Scientific Research 2, 892-898.

Adekunle, O.A., Adefalu, F.O., Oladipo, L.L., Adisa, R.S., Fatoye, A.D., 2009. Constraints to youth involvement in agricultural production in Kwara state, Nigeria. Agricultural Extension 13 (1), 102-108.

Barau, A.A., Afrad, S.I., 2017. Potentials of Rural Youth Agripreneurship in Achieving Zero Hunger. World Rural Observations. 9. 1-11. 10.7537/marswro090217.01.

Bennell, P., 2010. Investing in the future, creating opportunities for young rural people. Rome, IFAD, 5.

Brooks, K., Zorya, S., Gautam, A., 2012. Employment in agriculture; Jobs for Africa's youth, 2012 Global Food Policy Report, International Food Policy Research Institute (IFPRI).

Chaudhary, R., Janjhua, Y., Mehta, P., Sharma, N., Kumar, K.,2018. Factors limiting rural youth participation in agriculture based activities in tehsil Karsog in Himachal Pradesh. International Journal of Agricultural Science and Research 8 (3), 141-146.

CPD, 2004. Nature and impact of women's participation in economic activities in rural Bangladesh. Centre for Policy Dialogue (CPD) and International Rice Research Institute (IRRI) Policy Brief 7. Retrieved from http:// www.cpdbangladesh.org/. Accessed in January 2019.

Damar, R.K., 2008. A Study on participation of rural youth in agricultural activities in Jhabua district of Madhya Pradesh, Msc Thesis, submitted to Jawarlal Nehru Krishi Vishva Vidyalaya. Jabalpur, MP, India

FAO, 2014. Youth and agriculture: Key challenges and concrete solutions. Retrieved from:www.Fao.org/3/a-i3947.pdf. Accessed in January 2019.

Gangwar, R., Kameswari, V.L.V., 2016. Determinants of attitude of rural youth towards agriculture as means of livelihood. International Journal of Development 
Research 06(09), 9298-9300. Retrieved from http:// www.journalijdr.com. Accessed in January, 2019.

Jayapuria, D., 2015, A study on attitude of rural youth regarding participation in agricultural activities of Patan block of Jabanour district, Madhya Pradesh, Msc thesis, submitted to Jawarlal Nehru Krishi Vishva Vidyalaya, Jabalpur, MP, India

Kararach, G., Kobena, T.H., Frannie, A.L., 2011. Regional integration policies to support job creation for Africa's burgeoning youth population, The African Capacity Building Foundation (ACBF) Working Paper, 21.

Kwenye, J.M., Sichone, T., 2016. Rural youth participation in agriculture: exploring the significance and challenges in the control of agricultural sector in Zambian. RUFORUM Working Document Series, 14 (1), 473-477. Retrieved from http://repository.ruforum.org. Accessed in January 2019.

Mangal, H., 2009. Best practices for youth in agriculture: The Barbados, Grenada and Saint Lucia Experience. Final report.

Nandini S. , Kiresur V.R., 2013. Engendering rural livelihoods in Karnataka - A socioeconomic assessment. Agricultural and Economics Research. Reviews 26(2), 97-107.

Okoye, C.U., 1995. The rural economy and community banking in Nigeria. Rural development in Nigeria: concepts, processes and prospects. (Eds.): Eboh, E. C., Okoye, C. U. , D Ayichi, D. Auto-Century Publishing Company, Enugu. 200-215.

Oladeji, J.O., 2007. Effect of land degradation on income generating activities of farmers in Imo State, Nigeria. Journal of Economic Rural Development 16(1), 93-106.
Ovwigho B.O., 2014. Factors influencing involvement in nonfarm income generating activities among local farmers: the case of Ughelli South Local Government Area of 34 Delta State, Nigeria. Sustainable Agriculatural Research 3(1), 76-84.

Rani, A, Rampal, V.K., 2016. Involvement of rural youth in agricultural activities in Ludhiana district of Punjab, India. Indian Journal of Agricultural Research 50 (6), 528-534.

Rutta E., 2012. Current and emerging youth policies and initiatives with a special focus and links to agriculture: Tanzania (Mainland) case study. Food, Agriculture and Natural Resources Policy Analysis Network (FANRPAN), Pretoria, South Africa. Draft Report April, 2012.

Sharma, A., Bhaduri, A., 2009. The 'tipping point' in Indian agriculture: understanding the withdrawal of Indian rural youth. Agricultural manpower; Farmers; Employment; Occupational change; Labor; Agricultural and Food Policy; Consumer/Household Economics; Farm Management; Labor and Human Capital, 115130. Retrieved from http://ageconsearch.umn.edu/ record/127983/files/29.pdf. Accessed in January 2019.

Skuza, J.A., 2005. Site based youth development programmes: reaching understanding youth targeted communities. Journal of Extension 42, 20-26.

Swaminathan, M.S., 2001. "Shaping our agricultural future". The Hindu, Thursday, January 11, 2001.

Umunnakwe, Adedamola, Olajide, 2015. Socio-personal correlates of rural youth of Madhya Pradesh, India. International Journal of Agricultural Research Innovations and Technology 5 (1), 28-35. 